\title{
Analysis of the effectiveness of ultrasound and clinical examination methods in fetal weight estimation for term pregnancies
}

\section{Term gebelerde fetal ağırlı tahmininde ultrasonografi ve klinik muayane yöntemlerinin etkinliklerinin değerlendirilmesi}

\author{
Mehmet Zahran1, Yusuf Aytaç Tohma², Salim Erkaya1, Özlem Evliyaoğlu1 ${ }^{1}$, Eser Çolak ${ }^{1}$, Bora Çoşkun 1 \\ ${ }_{1}$ Etlik Zübeyde Hanım Womens's Health Teaching and Research Hospital, Department of Obstetrics and Gynecology, Ankara, Turkey \\ 2Başkent University Faculty of Medicine, Department of Obstetrics and Gynecology, Konya, Turkey
}

\begin{abstract}
Objective: To compare the accuracy of clinical and ultrasonographic (USG) estimation of fetal weight in non-complicated, term pregnancies.

Materials and Methods: Two hundred term pregnant women were included in the study. We used three formulae for the estimation of fetal weight at term; the Hadlock formula for the USG method, and two different formulas for clinical methods, maternal symphysis-fundal height and abdominal circumference at the level of umbilicus. Accuracy was determined by mean percentage error, mean absolute percentage error and proportion of estimates within $10 \%$ of actual birth weight (birth weight $\pm 10 \%$ ). Patients were divided into two groups according to actual birth weight, the normal birth weight group (2500-3999 g) and high birth weight group ( $\geq 4000 \mathrm{~g})$.

Results: All three methods statistically overestimated birth weight for the high and normal birth weight groups $(p<0.001, p=1.000, p=0.233)(p=0.037$, $\mathrm{p}<0.001$, and $\mathrm{p}<0.001$ ). For both groups, the mean absolute percentage errors of USG were smaller than for the other two clinical methods and the number of estimates were within $10 \%$ of actual birth weight for USG was greater than for the clinical methods; the differences were statistically significant $(\mathrm{p}<0.001)$. No statistically significant difference of accuracy was observed for all three methods for the high birth weight group ( $\mathrm{p}=0.365$, $\mathrm{p}=0.768$, and $\mathrm{p}=0.540$ ). However, USG systematically underestimated birth weight in this group.

Conclusion: For estimation of fetal birth weight in term pregnancies, ultrasonography is better than clinical methods. In the suspicion of macrosomia, it must be remembered that no method is better than any other. In addition, if ultrasonography is used, careful management is recommended because ultrasonography overestimates in this group.
\end{abstract}

Keywords: Fetal weight, birth weight, ultrasonography

$\ddot{O} z$

Amaç: Komplike olmayan term gebeliklerin fetal ağırlık tahmininde ultrasonografi (USG) ve klinik muayene yöntemlerinin etkinliklerinin değerlendirilmesi. Gereç ve Yöntem: Bu çalışmada uygun özellikteki 200 gebede fetal ağırlık tahmini için üç farklı yöntem kullanılmıştır. Sonografik yöntem olarak 3 parametreli Hadlock formülü, klinik muayene yöntemleri olarak ise annenin simfizis-pubis mesafesi ve umbilikus seviyesinden anne karın çevresi ölçümlerinin kullanıldığı formüller kullanılmıştır. Yöntemlerin etkinliğini değerlendirmek için ortalama yüzde hata, ortalama mutlak yüzde hata ve gerçek doğum ağırlığının $\pm \% 10$ aralığına giren tahmin oranları kullanılmıştır. Çalışmanın yapıldığı popülasyon, gerçek doğum ağırlı̆̆ına göre tüm olgular, doğum ağırlı̆ı normal olan olgular (2500-3999 gr) ve doğum ağırlı̆̆ı normalden fazla olan ( $\geq 4000$ gr) olgular grubu olarak ikiye ayrılmıştır.

Bulgular: Tüm olgular grubunda ve normal doğum ağırlı̆̆ olan olgular grubunda her üç yöntemle de istatistiksel olarak daha büyük tahminler yapılmıştır $(\mathrm{p}<0,001, \mathrm{p}=1,000, \mathrm{p}=0,233)(\mathrm{p}=0,037, \mathrm{p}<0,001$ ve $\mathrm{p}<0,001)$. Her iki grup için ultrasonografik yöntemin ortalama mutlak yüzde hatası klinik yöntemlerden istatistiksel olarak küçük, $\pm \% 10$ aralığına giren tahminlerin sayısı ise istatistiksel olarak daha büyük bulunmuştur (p<0,001). Normalden fazla doğum ağırlığı olan olgular grubunda üç yöntemin etkinlikleri arasında ise istatistiksel olarak anlamlı bir farklılık görülmemiştir $(\mathrm{p}=0,365$, $\mathrm{p}=0,768$ ve $\mathrm{p}=0,540)$. Fakat bu grupta USG ile sistematik olarak daha küçük tahminler yapılmaktadır.

Sonuç: Normal, term gebeliklerde doğumdan önce fetal ağırlık tahmininde tüm popülasyon ve normal fetal ağırlı̆̆a sahip olgularda USG yönteminin daha üstün olduğu görülmüştür. Fakat makrozomiden şüphelenildiğinde yöntemlerin birbirlerine üstünlügünün olmadığı hatırlanmalıdır ve eğer ölçüm USG yöntemiyle yapıldı ise bu grupta ultrasonla daha küçük tahmin yapıldığından ölçüm sonucunu değerlendirme ve yönetimde dikkatli olunmalıdır.

Anahtar Kelimeler: Fetal ağırlık, doğum ağırlı̆̆l, ultrasonografi

Address for Correspondence/Yazışma Adresi: Yusuf Aytaç Tohma, MD,

Başkent University Faculty of Medicine, Department of Obstetrics and Gynecology, Konya, Turkey

Phone: +90 5555640315 E-mail: aytactohma@hotmail.com

Received/Geliş Tarihi : 07.09.2015

Accepted/Kabul Tarihi : 26.11.2015 
PRECIS: We evaluated the effectiveness of ultrasound and clinical examination methods for fetal weight estimation.

\section{Introduction}

Over the last two or three decades, fetal weight estimation has almost become a routine antepartum test in the management of high-risk pregnancies and birth. The two methods used in modern obstetrics practice are the clinical evaluation of fetus weight and ultrasound. Through the late 1960s, external clinical examination became the most frequently and widely used method for the determination of fetus weight and dimensions. Studies have shown that $80-85 \%$ of clinical estimations were between \pm 500 grams of the actual birth weight (ABW) and $69 \%$ were between $\pm 10 \%(1,2)$. However, the use of clinical methods has decreased with the increased use of ultrasonographic (USG) for fetal weight estimation in recent years. Studies have shown that the mean absolute percentage failure rate of USG estimations generally range between $6 \%$ and $12 \%$, and the estimation rate of actual birth weight, which was $\pm 10 \%$, was between $40 \%$ and $80 \%(3-6)$.

Various researchers have suggested that palpation of the uterus is insufficient for the estimation of fetal weight $(7,8)$. Ultrasound, as a technical, objective, and repeatable method, is generally perceived as superior to clinical estimation. Studies in the literature that compared the two methods found different results(9-11). These studies often involved estimations through evaluation of uterus size externally with use of a physician's hands. This method is the oldest and most popular method and there have been doubts about its use because it is not objective. Therefore, it would be beneficial to use a simple, easy, cheap, but standard and objective clinical method as an alternative to USG, which is expensive and not always easy to access, especially in countries with limited financial resources for health. There are objective and standard clinical methods; however, the number of studies that evaluate the effectiveness of these methods or compare them with USG, is quite low.

The purpose of this study was to compare the accuracy of clinical and USG estimation of fetal weight in non-complicated term pregnancies.

\section{Materials and Methods}

This prospective single-center study was approved by the local ethics committee of Etlik Zübeyde Hanım Women's Health Teaching and Research Hospital and informed consent was obtained from all the patients. Two hundred women with term pregnancies, who were consecutively admitted to our department between November 10th 2008, and August 29th 2009, were included in the study. All pregnancies were at 37 gestational weeks with normal amniotic fluid index (50-200 mm), vertex presentations and labor had not yet begun. In a number of patienst, a vaginal examination during labor concluded with a maximum $3 \mathrm{~cm}$ dilatation and $60 \%$ effacement. The lowest part of the fetal head was over the interspinal line and the engagement had not yet begun. Gestational week was identified through counting the days according to the last menstrual period or a USG measurement performed before the 22nd week of pregnancy. Exclusion criteria were polyhydramnios, preterm labor, multiple pregnancy, intrauterine growth retardation, early membrane rupture, abnormal presentation, antepartum hemorrhage, eclampsia, preeclampsia, gestational diabetes mellitus (GDM), known congenital fetal anomaly, systemic disease in the mother, and placental anomalies.

Patients that fulfilled the study criteria were registered on the monitoring chart including their name and surname, age, height, weight, gravida, parity and pregnancy age. Next, a clinical examination was made when they were lying on their back with their hands on both sides, legs stretched, and with an empty bladder. First, the distance between the symphysis pubis mid point of the top corner and the uterus fundus top point was measured on the naked abdomen of the mother using a nonflexible, curved tape measure (SPFU). In addition, abdominal circumferences of the mother at the umbilicus level (AP) were measured in centimeters. Ultrasound predicted fetus weight was then measured in grams and recorded. All USG measurements were performed using a Logic P 5 USG device, which had a $3200 \mathrm{MHz}$ trans-abdominal probe; a three-parameter Hadlock formula [biparietal diameter (BPD), femur length (FL), and abdominal circumference (AC)] was used. All sonography and clinical measurements were performed on the same day by the same researcher, who was in his fifth year as an assistant.

For the BPD measurement, the greatest distance between the outside corner of the front parietal bone and the inner corner of the back parietal bone was measured at a right angle using electronic indicators on the frozen image, where falx cerebri echo was observed at the mid-line, the thalamus were monitored symmetrically on both sides; the cavum septum pellucidum was $1 / 3$ of the distance from the frontal occipital. On the same platform, occipitofrontal diameter (OFD) was measured from the outside corner of the frontal bone to the outside corner of the occipital bone, parallel to the falx cerebri with a right angle to the BPD. Cephalic index (BPD/OFDx100) was calculated in order to exclude dolichocephaly and brachiocephalic. The cephalic index value was included in the study and was between 0.77 and 0.83 . Where all long axes of the femur were monitored, the distance between the two ends of the diaphysis was measured for FL, without including the femoral head and distal epiphysis. With respect to the AC measurement, first, using the fetal spine or fetal aorta, the direction of the longitudinal axis of the fetal body was identified. The fetal umbilical vein was obtained, along with a circular and symmetric abdominal image at a right angle to these structures at the level of the stomach. On the platform, where the umbilical vein was monitored at the front $1 / 3$ it gave the portal branch, the stomach was monitored without monitoring the heart and bladder, and a chamber 
surrounding the skin echo from the outside corner to the other outside corner was created and measurements were performed. Following the recording of the three biometric data, fetal weight was automatically measured and recorded using the USG device. The mother was monitored in the delivery room.

Two formulas were used for clinical estimations. In the first formula, SPFU and AP were multiplied in centimeters and TFW was calculated in grams.

Formula 1: TFW $(\mathrm{g})=\mathrm{SPFU}(\mathrm{cm})$ x AP $(\mathrm{cm})$

The Jonson formula was used as the second formula.

Formula 2: TFW $(\mathrm{g})=(\mathrm{SPFU}(\mathrm{cm})-\mathrm{n}) \times 155(\mathrm{n}=12$ was used because engagement was not experienced in all cases). Where the weight of the mother was equal to more than $91 \mathrm{~kg}, 1 \mathrm{~cm}$ was reduced from the fundus height.

Fetal weight estimations obtained through the three different methods were registered in the monitoring chart. Finally, a nurse measured actual birth weight in grams using an electronic scale within the first 10 minutes after birth; actual weight was recorded along with the time between examinations and birth. The patients in the study were divided into two groups according to the postpartum measured actual fetal birth weight; group 1 with actual birth weight of 2500-3999 g and group 2 with actual birth weight $\mathrm{t}$ equal to or more than $4000 \mathrm{~g}$. In order to determine the performance of USG: formula 1 and formula 2 were used to predict intrauterine fetal weight at the prenatal stage; and mean failure percentage (MFP) [(predicted birth weight-actual birth weight) x 100/actual birth weight]; mean absolute failure percentage (MAFP) (absolute value (predicted birth weight -actual birth weight) x 100/actual birth weight) values; and the percentage of estimations that could predict actual birth weight within $\pm 5 \%$, $\pm 5.1-10.0 \%, \pm 10.1-20.0 \%$, and more than $20.0 \%$ of failure were calculated separately for each method in all three groups. In all groups, the amount of failure in estimations made using the BlandAltman method (bias) and 95\% confidence intervals of the fitness level were calculated. Furthermore, estimation rates belonging to the standard deviation value of 1 and standard deviation value of $\pm 375 \mathrm{~g}$ were calculated in all groups for formula 1 and formula 2 .

\section{Results}

Two hundred women whose pregnancies were at the 37 th gestational week with normal amniotic fluid index (50-200 $\mathrm{mm}$ ), vertex presentations, and labor had not yet begun, were included in the study. Demographic characteristics of the women are shown in Table 1.

Birth weight was less than 4000 grams in $88 \%(n=176)$ of the women and more than 4000 grams in $12 \%(n=24)$. In the group where actual birth weight was less than $4000 \mathrm{~g}$, and fetal weights were estimated with USG, formula 1 and formula 2 were statistically significantly higher $(\mathrm{p}=0.037, \mathrm{p}<0.001$, and $\mathrm{p}<0.001$ ), respectively. Birth weights estimated with formula 1 and formula 2 were statistically significantly higher than birth weights estimated with USG ( $p<0.001)$. In addition, birth weights estimated with formula 2 were statistically significantly higher than birth weights estimated with formula $1(\mathrm{p}<0.001)$ (Table 2).

In the group where the actual birth weight was $4000 \mathrm{~g}$ and higher, birth weight estimated with USG was statistically significant and a mean of $201 \mathrm{~g}$ less than the actual birth weight $(\mathrm{p}<0.001)$. Birth weight estimated with formula 1 was a mean 39 g less than actual birth weight and was not found to be statistically significant $(\mathrm{p}=1.000)$. Birth weight estimated with formula 2 was a mean $48 \mathrm{~g}$ less than actual birth weight and again was not found to be statistically significant (Figure 1). The difference between USG and formula 1 was not found to be statistically significant $(\mathrm{p}=0.233)$, but birth weight estimated with formula 2 was 249 g higher than with USG, which was statistically significant $(\mathrm{p}=0.008)$. In addition, the mean difference estimated with formula 1 was $88 \mathrm{~g}$ higher than with formula 2; this was not statistically significant ( $\mathrm{p}=0.642$ ) (Table 3 ).

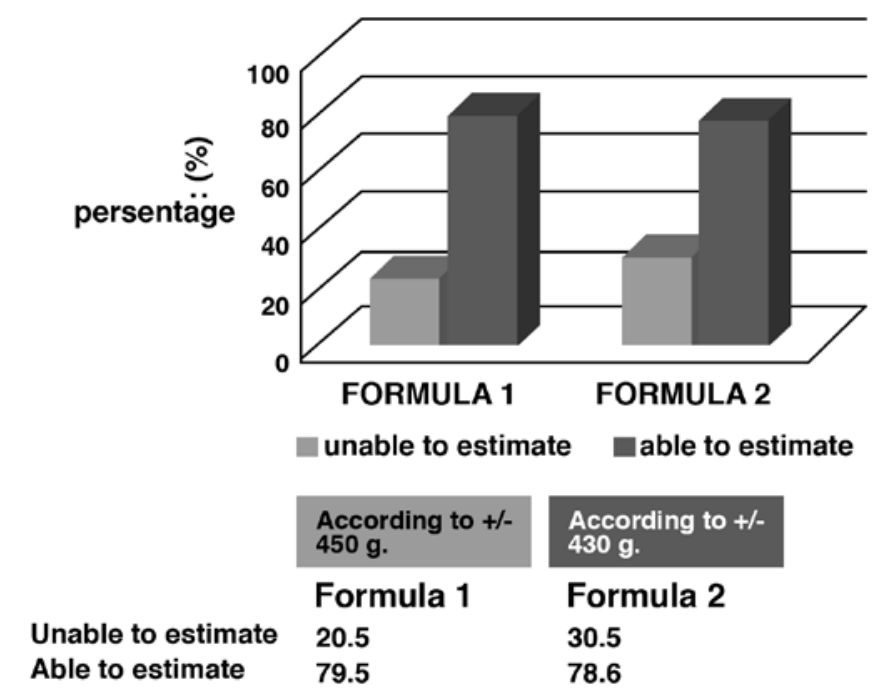

Figure 1. Estimation rates for formula 1 and formula 2 for 1 standard deviation level

Table 1. Demographical characteristics of all cases

\begin{tabular}{lllll}
$\begin{array}{l}\text { Variables } \\
\text { (n=200) }\end{array}$ & Average & $\begin{array}{l}\text { Standard } \\
\text { deviation }\end{array}$ & Median & Range \\
\hline Age (years) & 26.8 & 5.1 & 26 & $(18-42)$ \\
\hline Weight $(\mathrm{kg})$ & 76.6 & 11.3 & 75 & $(49-115)$ \\
\hline Height (cm) & 161.6 & 6.2 & 163 & $(145-180)$ \\
\hline $\begin{array}{l}\text { Gravida } \\
\text { Parity }\end{array}$ & 2.1 & 1.1 & 2 & $(1-7)$ \\
$\begin{array}{l}\text { Gestational age } \\
\text { (weeks) }\end{array}$ & 39.1 & 3.1 & 39 & $(37-43)$ \\
$\begin{array}{l}\text { Interval (the } \\
\text { number of } \\
\text { days between } \\
\text { measurements and } \\
\text { births) }\end{array}$ & 0.49 & 1.089 & 0.00 & $(0-7)$ \\
\hline
\end{tabular}




\section{Conclusion}

Although some researchers found sonographic estimations better than clinical estimations, $(9,10)$ others reported that the success of both methods was similar or that the clinical method was better(11,12). The differences in the conclusions might have been influenced by non-homogenous samples: term and preterm fetuses were evaluated together, maternal demographic characteristics were different, small sample sizes, different sonographic and clinical methods used, and variations in definitions and diversity of statistical analyses performed. It is important to ensure standardization in such studies because of the redundancy of reasons that cause differences. In order to do this, in our study we included pregnant women who were in the $37^{\text {th }}$ week or later stage of pregnancy, whose actual birth weight is $2500 \mathrm{~g}$ and higher, who are singular, in vertex presentation, with Anxiety sensitivity index (ASI) within normal limits, no fetal macroscopic anomalies detected before and after birth, no known maternal systemic disease and complications, and who were not yet in labor or whose labor had just started. Principally, we aimed to assess ultrasound and clinical examination of fetal

Table 2. Comparison of actual birth weight (ABW) with ultrasonographic, formula 1 and formula 2 using Bonferroni corrected multiple comparison test in patients with ABW <4000 g

\begin{tabular}{|lllllll}
\hline ABW & $\begin{array}{l}\text { Mean } \\
\text { difference } \\
(\mathrm{g})\end{array}$ & $\begin{array}{l}\text { Standard } \\
\text { deviation } \\
(\mathrm{g})\end{array}$ & $\begin{array}{l}\mathrm{p} \\
\text { value }\end{array}$ & $\begin{array}{l}\text { 95\% Confidence } \\
\text { interval }\end{array}$ & $\begin{array}{l}\text { Lower } \\
\text { limit }\end{array}$ & $\begin{array}{l}\text { Upper } \\
\text { limit }\end{array}$ \\
\hline USG & -57.114 & 20.592 & 0.037 & -112.066 & -2.161 \\
\hline Formula 1 & -161.131 & 23.090 & $\leq 0.001$ & -222.749 & -99.513 \\
\hline Formula 2 & -271.830 & 22.843 & $\leq 0.001$ & -332.789 & -210.870 \\
\hline ABW: Actual birth weight, USG: Ultrasonographic & & \\
\hline
\end{tabular}

weight estimation in term pregnancies under normal conditions. In studies of fetal weight estimation, generally two statistical parameters have been used in the evaluation of effectiveness; Mean absolute percentage error (MAPE) (with Mean error percentage) and estimation rates were within \pm 5 - $10 \%$ of actual birth weight. In the literature, it was observed that the MAPE given for the success of sonographic estimations was between $6 \%$ and $12 \%$ and the estimation rate within $\pm 10 \%$ was between $40 \%$ and $80 \%(9,10)$. When we looked at the success rates of clinical estimations, $80-85 \%$ of estimations were within \pm 500 $\mathrm{g}$ of the actual birth weight and $55-72 \%$ of estimations were within $\pm 10 \%$ of the actual birth weight; the MAPE varied between $7.5 \%$ and $19.8 \%$ in term pregnancies $(1,2)$.

In our study, it was observed that all three methods estimated birth weight systematically higher in the group in which actual birth weight was less than $4000 \mathrm{~g}$. According to the BlandAltman method, the differences among groups were found to be statistically significant. The order of most successful estimations was USG $>$ formula $1>$ formula 2 . In the group in which birth weight was $4000 \mathrm{~g}$ and higher, both MAPE values and rates of estimation within $\pm 5 \%$ and $\pm 10 \%$ ranges were found to be similar. As in the group with normal birth weight, USG was most successful, formula 1 was on moderately successful, and formula 2 was least successful in terms of estimation within acceptable limits for all participants.

In the group in which birth weight was higher than $4000 \mathrm{~g}$, the MAPE values of all three methods were lower and estimation rates within $\pm 10 \%$ were higher compared with the other two groups. However, it was observed that MAPE values ( $\mathrm{p}=0.452$ and $\mathrm{p}=0.369$ ), and estimation rates of actual birth weight within $\pm 10 \%(\mathrm{p}=0.432$ and $\mathrm{p}=0.632)$ were similar for USG and formula 1 in both $<4000 \mathrm{~g}$ and $\geq 4000 \mathrm{~g}$ groups; there was no statistically significant difference between them. However, although the MAPE values were found to be lower for formula

Table 3. Comparison of actual birth weight (ABW), ultrasonographic, formula 1 and formula 2 byusing Bonferroni corrected multiple comparison test in patients with ABW ntsents

\begin{tabular}{|c|c|c|c|c|c|c|}
\hline & & $\begin{array}{l}\text { Mean } \\
\text { difference (g) }\end{array}$ & $\begin{array}{l}\text { Standard } \\
\text { deviation (g) }\end{array}$ & $\begin{array}{l}\text { p value } \\
\text { Lower } \\
\text { limit }\end{array}$ & $\begin{array}{l}\text { 95\% Conf } \\
\text { Upper lim }\end{array}$ & e interval \\
\hline & USG & 201.000 & 44.919 & $\leq 0.001$ & 71.353 & 330.647 \\
\hline \multirow{2}{*}{ ABW } & Formula 1 & 39.417 & 85.795 & 1.000 & -208.210 & 287.043 \\
\hline & Formula 2 & -48.708 & 75.268 & 1.000 & -265.951 & 168.535 \\
\hline \multirow{3}{*}{ USG } & Formula 1 & -161.583 & 73.734 & 0.233 & -347.400 & 51.233 \\
\hline & Formula 2 & -249.708 & 68.302 & 0.008 & -446.846 & -52.571 \\
\hline & ABW & -201.000 & 44.919 & $\leq 0.001$ & -330.647 & -71.353 \\
\hline \multirow{3}{*}{ Formula 1} & USG & 161.583 & 73.734 & 0.233 & -51.233 & 374.400 \\
\hline & Formula 2 & -88.125 & 52.539 & 0.642 & -239.767 & 63.517 \\
\hline & ABW & -39.417 & 85.795 & 1.000 & -287.043 & 208.210 \\
\hline
\end{tabular}


2 in the $\geq 4000$ g group compared with the $<4000$ g group ( $\mathrm{p}=0.025$ ), the estimation rate within $\pm 10 \%$ was found to be significantly higher $(\mathrm{p}=0.046)$. Consequently, it can be said that formula 2 was successful with large fetuses.

With few exceptions, standard and objective methods have not been used for clinical estimation in previous studies; estimations were made by examining the uterus with external palpation and with Leopold maneuvers. In this study, we used 2 more objective and standard clinical examination methods. Until the early 1990's, it was generally accepted that USG was superior to clinical estimation in fetal weight estimation without any scientific grounds. Clinical methods were largely neglected in line with the popularization of USG devices. Following the studies of Chauhan and many other researchers in which the authors reported that clinical estimations were as successful as USG, prejudices on this matter started to change(13-15). Sherman et al.(9) compared external examination and USG (ShepardHadlock) in 1717 fetuses with a mean birth weight of 3334 g, $85 \%$ of which were term and had no membrane rupture. The authors observed that USG systematically estimated lower in the $2500-4000 \mathrm{~g}$ range and the estimation rate within $\pm 10 \%$ was $70.6 \%$. There were no systematic errors in the clinical method whose rate was $75.1 \%$; the authors concluded that the clinical method was superior to USG for normal-weight fetuses. For $4000 \mathrm{~g}$ and higher, they found that estimation rates within $\pm 10 \%$ were $58.8 \%$ for USG and $61.3 \%$ for the clinical method; both methods estimated systematically lower but there was no statistically significant difference between the two methods. The lowest error and highest estimation rates with both methods were obtained in the group of fetuses with normal weight ${ }^{(15)}$. Baum et al.(16) reported that USG was not superior to the clinical and mother's estimation, and Watson et al.(11) reported that there was no difference between the two methods, even in extreme term weights(16). In two different studies that compared the two methods, error rates were found to be less than $10 \%$ and no superiority of one method over the other was reported(17). One of the few studies in which the effectiveness of the clinical method compared to USG in terms of fetal weight estimation was carried out by Shittu et al.(18) in Nigeria in 2004. In their study of 100 pregnant women, which resembles our population, the authors compared Hadlock 2(19) and formula 1 and reported that neither of the two methods was superior the other in the

Table 4. Comparison of Shittu et al.(18) and present study for formulal

\begin{tabular}{|llll} 
& & AAEP & $\begin{array}{l} \pm 10 \% \\
\text { Ratio }\end{array}$ \\
\hline Shittu et al.(18) & Formula 1 & $9.8 \pm 8.3$ & 70.6 \\
& USG & $10.2 \pm 9.1$ & 64.7 \\
\hline Present study & Formula 1 & $7.86 \pm 6.09$ & 70.9 \\
& USG & $5.99 \pm 3.80$ & 83.4 \\
\hline AAEP: American Association for Emergency Psychiatry, USG: Ultrasonographic
\end{tabular}

whole sample of 2500-3999 $\mathrm{g}$ and $4000 \mathrm{~g}$ and higher fetuses. In all three groups, systematically lower estimations were made with USG and higher estimations were made with clinical methods. In Shittu et al.(18) study, the number of fetuses that weighed 4000 $\mathrm{g}$ and higher was 17 . When we compared the MAPE values and the estimation rates within $\pm 10 \%$ for 24 patients in the same group in our study with those found by Shittu et al.,(18) it was observed that better results were obtained in large fetuses with both methods, except in the $\pm 10 \%$ ratio for formula 1 (Table 4 ). Görgen et al.(20) estimated fetal weight in 574 singular pregnant women who were in the 34th-42nd week of pregnancy, whose actual birth weight was 2050-5550 g, and had variable vertex presentation with Johnson formula (formula 2) by measuring SPFY and reported that $72.3 \%$ of their measurements were within $\pm 10 \%$ of actual birth weights(20). The estimation rate of Görgen et al.(20) for this difference was 75.6\%. In our study, the estimation rate within $\pm 10 \%$ for formula 2 was $56 \%$, the estimation rate for \pm 375 g level was $62 \%$, and for 1 SD value of $\pm 430 \mathrm{~g}$ was $78.6 \%$, which were similar to the other two studies. Physicians will not always encounter pregnant women with standard characteristics as in this study. Therefore, it is necessary to investigate the effectiveness of USG in different pregnant populations. These can be listed as the most frequently encountered preterm labor, fetuses lighter than $2500 \mathrm{~g}$, oligohydramnios, early membrane rupture, preterm premature rupture of membranes, breech presentation, maternal obesity, and GDM.

In our study, labor did not begin in all groups and engagement of fetal head had not occurred in the latent-or early phase. Amniotic membranes were intact, ASI was within normal limits, and all fetuses were in vertex presentation. In a study of 218 fetuses, Çelik(21) reported that sonographic estimations, carrying out the labor in active and latent phase, and presence of membrane rupture had no significant impact on the success of estimation(22). Benacerraf et al.(3) reported that oligohydramnios and polihydramnios did not affect the estimation success following their study of 1301 fetuses, whereas Barnhard et al.(23) suggested that estimations should be made before amniotomy because oligohydramnios significantly reduces the success of sonographic and clinical estimations. Scioscio et al.(24) determined no difference between cephalic and non-cephalic presentations. Blann(25) reported that cervical dilatation and head level were not effective on sonographic and clinical estimation.

In our study, ultrasonographic and clinical measurements were carried out on the same day and all deliveries occurred within seven days of the estimation. Some $90.5 \%$ of the deliveries occurred on the same day and no corrections were made for time difference. The weight of fetuses increased by a mean 25$30 \mathrm{~g}$ a day and 200-250 $\mathrm{g}$ a week during term. In the study of Benacerraf et al.(3) on 1301 pregnant women, intervals varied between 0-7 days as in our study, and $80 \%$ of the women gave birth between the $1^{\text {st }}$ and $5^{\text {th }}$ days. The additional time did not 
affect the results(3). No corrections were made for additional time because all of the births in our study occurred within 7 days and 94\% occurred within the first 48 hours.

These results will be valuable and useful in groups with similar characteristics to the patients in this study. However, pregnant women with these characteristics will not be encountered in daily practice. Therefore, studies should be performed that compare USG and objective clinical examination methods, various commonly used ultrasound methods, and include various obstetric populations such as preterm labor, membrane rupture, various labor phases, GDM, non-vertex presentations.

\section{Authorship Contributions}

Ethics Committee Approval: The study were approved by the of Local Ethics Committee of Etlik Zübeyde Hanm Womens's Health Teaching and Research Hospital, Informed Consent: Consent form was filled out by all participants, Concept: Mehmet Zahran, Salim Erkaya, Design: Mehmet Zahran, Özlem Evliyaoğlu, Data Collection or Processing: Bora Çoşkun, Analysis or Interpretation: Yusuf Aytaç Tohma, Eser Çolak, Literature Search: Eser Çolak, Writing: Yusuf Aytaç Tohma, Peer-review: Externally peer-reviewed, Conflict of Interest: No conflict of interest was declared by the authors, Financial Disclosure: The authors declared that this study has received no financial support.

\section{References}

1. Insler V, Bernstein D, Ricover M, Segal T. Estimation of fetal weight in simple external palpation. Am J Obstet Gynecol 1967;98:292-3.

2. Ong HC, Sen DK. Clinical estimation of fetal weight. Am J Obstet Gynecol 1972;112:877-80.

3. Benacerraf BR, Gelman R, Rigoletto FD. Sonographically estimated fetal weights: Accuracy and limitation. Am J Obstet Gynecol 1988;159:1118-21.

4. Dudley NJ. A systematic review of the ultrasound estimation of fetal weight. Ultrasound Obstet Gynecol 2005;25:80-9.

5. Balsyte D, Schäffer L, Burkhardt T, Wisser J, Kurmanavicius J. Sonographic prediction of macrosomia cannot be improved by combination with pregnancy-specific characteristics. Ultrasound Obstet Gynecol 2009;33:453-8.

6. Ben-Haroush A, Yogev Y, Hod M, Bar J. Predictive value of a single early fetal weight estimate in normal pregnancies. Eur J Obstet Gynecol Reprod Biol 2007;130:187-92.

7. Mongelli M, Benzie R. Ultrasound diagnosis of fetal macrosomia: a comparison of weight prediction models using computer simulation. Ultrasound Obstet Gynecol 2005;26:500-3.

8. Chien PF, Owen P, Khan KS. Validity of ultrasound estimation of fetal weight. Obstet Gynecol 2000;95:856-60.
9. Sherman DJ, Arieli S, Tovbin J, Siegel G, Caspi E, Bukovsky IA. A comparison of clinical and ultrasonic estimation of fetal weight. Obstet Gynaecol 1998;91:212-7.

10. Chauhan SP, Hendrix NW, Magann EF, Morrison JC, Jenney SP, Devoe LD. Limitations of clinical and sonographic estimates of birth weight: experience with 1034 parturients. Obstet Gynecol 1998;91:72-7.

11. Watson WJ, Soisson AP, Harlass FE. Estimated weight of the term fetus: Accuracy of ultrasound vs. clinical examination. J Reprod Med 1988;33:369-71.

12. Fox NS, Bhavsar V, Saltzman DH, RebarberA, Chasen ST. Influence of maternal body mass index on the clinical estimation of fetal weight in term pregnancies. Obstet Gynecol 2009;113:641-5.

13. Chauhan SP, Christie TL, Hess LW. Rapid estimation of birth weights: ask the mother. N Engl J Med 1992;326:1504.

14. Lindell G, Marsal K, Kallen K. Impact of maternal characteristics on fetal growth in the third trimester: a population-based study. Ultrasound Obstet Gynecol 2012;40:680-7.

15. Albouy-Llaty M, Thiebaugeorges O, Goua V, Magnin G, Schweitzer M, Forhan A, et al. Influence of fetal and parental factors on intrauterine growth measurements: results of the EDEN mother-child cohort. Ultrasound Obstet Gynecol 2011;38:673-80.

16. Baum JD, Gussman D, Stone P. Clinical and patient estimation of fetal weight vs. ultrasound estimation. J Reprod Med 2002;47:194-8.

17. Watson WJ, SoissonAP, Harlass FE. Estimated weight of the term fetus: Accuracy of ultrasound vs clinical examination. J Reprod Med. 1988;33:369-71.

18. Shittu AS, Kuti O, Orji EO, Makinde NO, Ogunniyi SO, Ayoola OO, et al. Clinical versus sonographic estimation of foetal weight in Southwest Nigeria. J Health Popul Nutr. 2007;25:14-23.

19. Melamed N, Ben-Haroush A, Meizner I, Mashiach R, Glezerman M, Yogev Y. Accuracy of sonographic weight estimation as a function of fetal sex. Ultrasound Obstet Gynecol 2011;38:67-73

20. Görgen H, Kuyumcuoğlu U, Ergün B, Api M. Fundus-pubis ölçümü ile fetal ağırlık tahmini. Perinatoloji Dergisi 1994;2:85-8.

21. Çelik Hİ. İntrapartum yapılan ultrasonogafik fetal ağırlık tahminlerinin postpartum gerçek fetal ağırlık ile karşılaştırılması, eylemin fazlarının ve membrane rüptürünün yapılan tahmin üzerine etkisinin araştırılması, Uzmanlık Tezi. İstanbul, 2006;22s.

22. Souka AP, Papastefanou I, Michalitsi V, Pilalis A, Kassanos D. Specific formulas improve the estimation of fetal weight by ultrasound scan. J Matern Fetal Neonatal Med 2014;27:737-42.

23. Barnhard Y, Bar-Hava I, Divon MY. Accuracy of intrapartum estimates of fetal weight: Effect of oligohydramnios. J Reprod Med 1996;4:907-10.

24. Scioscio M. Estimation of birth weight by two dimensional ultrasonography. Obstetrics Gynecology. 2008;1:111.

25. Blann DW. Estimaion of fetal weight before and after amniotomy in the laboring gavid women. Am J Obstet Gynecol 2000;182:1117-20. 